\title{
Theatres in India after Independence with Special Reference to Mahesh Dattani's works
}

\author{
Dr. Shobha Kumari
}

English Teacher, Project Adarsh Kenya H/S Cum Inter College, Pachrukhi, Siwan Bihar, India

\begin{abstract}
Theater in India as its very ancient origin. The earliest form of classical theater of India was the Sanskrit theater. Modern Indian theater developed during the period of colonial rule under the British Empire. In order to restrict the use of the theater the British government imposed dramatic Performance act. But after independence the use of theater flourished and gradually kept on improving. Accordingly the new narrative style and techniques also developed. Theaters across all over India evolved and embellished with different names in different regions. Among the many forms of Indian folk theatre. Bhavai is a popular folk theatre form of Gujarat, Bhaona and AnkiyaNats have been practicing

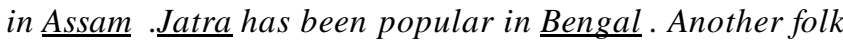
theatre form popular in Haryana, Uttar

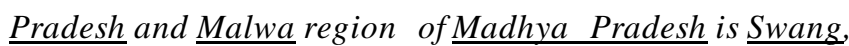
which is dialogue-oriented rather than movementoriented. Yakshagana is a very popular theatre art in Karnataka. Kathakali is a form of dance-drama, characteristic of Kerala. The various dramatist since early 19th century to the modern era have been experimenting on dramaturgy and hence improvising the narrative techniques since independence. In this paper I have specially discussed Mahesh Dattani's technical craftsmanship, their skillful enactment on stage, how it becomes effective with his stage directions.Dattani's plays are crafted meticulously and the dramatic tensions are carefully built up. Most of his plays have the feministic aspects and the gender biased issues of today's society.
\end{abstract}

Keywords- Dramaturgy, Narrative Techniques, Meticulously.

\section{INTRODUCTION}

Theatre in India has its very ancient origin. The earliest form of classical theatre of India was the Sanskrit theatre. Modern Indian theatre developed during the period of colonial rule under the BritishEmpire. In order to restrict the use of the theatre the British government imposed dramatic Performance act. But after independence the use of theatre flourished and gradually kept on progressing. Accordingly the new narrative style and techniques also developed. Theatres across all over India evolved and embellished with different names in different regions. Among the many forms of Indian folk theatre, Bhavai is a popular folk theatre form of Gujarat, Bhaona and AnkiyaNats have been practicing in Assam .Jatra has been popular in Bengal. Another folk theatre form popular in Haryana, Uttar

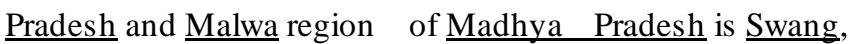
which is dialogue-oriented rather than movementoriented. Yakshagana is a very popular theatre art in Karnataka.Kathakali is a form of dance-drama, characteristic of Kerala.The various dramatist since early 19th century to the modern era have been experimenting on dramaturgy and hence improvising the narrative techniques since independence.

\section{Meaning of Drama and Theatre}

Drama is the specific mode of fiction represented in performance:

a play performed in a theatre, or on radio or television. ${ }^{[1]}$ Considered as a genre of poetry in general, the dramatic mode has been contrasted with the epic and the lyrical modes ever since Aristotle's Poetics (c. 335 $\mathrm{BC}$ - the earliest work of dramatic theory. ${ }^{[2]}$ Drama is a word that comes from Greek Dran, which means to do or perform. It literally means action. Drama has many forms and must be construed as a generic term taking on many forms, one of which is theater. The act or process of performing a play in front of an audience is dramatization. Drama can be an episode of life, such as $9 / 11$, a section in a DVD library or a library of plays, or it can be a fiction full of emotions and conflicts.

The term "drama" comes from a Greek word meaning "action" (Classical Greek: $\delta \rho \tilde{\alpha} \mu \alpha$, drama), which is derived from "I do" (Classical Greek: $\delta \rho \alpha ́ \omega, d r a o)$. The two masks associated with drama represent the traditional generic division between comedy and tragedy. They are symbols of the ancient Greek Muses, Thalia, and Melpomene. Thalia was the Muse of comedy (the laughing face), while Melpomene was the Muse of tragedy (the weeping face) 
Modern Indian drama: Rabindranath Tagore was a pioneering modern playwright who wrote plays noted for their exploration and questioning of nationalism, identity, spiritualism and material greed. ${ }^{[4]}$ His plays written in Bengali and include Chitra (Chitrangada, 1892), The King of the Dark Chamber(Raja, 1910), The Post Office (Dakghar, 1913), and Red Oleander (Raktakarabi, 1924). GirishKarnad is a noted playwright, who has written a number of plays that use history and mythology, to critique and problematize ideas and ideals that are of contemporary relevance. Karnad's numerous plays such as Tughlaq, Hayavadana, Taledanda, and Naga-Mandala are significant contributions to Indian drama. Vijay Tendulkar and Mahesh Dattani are amongst the major Indian playwrights of the 20th century. Mohan Rakesh in Hindi and Danish Iqbal in Urdu are considered architects of new age Drama. Mohan Rakesh's AadheAdhoore and Danish Iqbal's 'Dara Shikoh' are considered modern classics Theatre or theater ${ }^{[5]}$ is a collective form of fine art that uses live performers, typically actors or actresses, to present the experience of a real or imagined event before a live audience in a specific place, often a stage. The performers may communicate this experience to the audience through combinations of gesture, speech, song, music, and dance. Elements of art, such as painted scenery and stagecraft such as lighting are used to enhance the physicality, presence and immediacy of the experience. ${ }^{[6]}$ Modern theatre includes performances of plays and musical theatre. The art forms of ballet and opera are also theatre and use many conventions such as acting, costumes and staging. Theatre is the personification of a drama on stage. It requires space, individuals who play characters, and people who see the act (audience). Theater is a collective effort of many people, dramatist or a playwright, a director, actors, and technicians to make audience believe that whatever is happening on stage is real. Theater is a very important performing art, and with passage of time, it has taken many new forms such as television soap operas and even movies, where there are rehearsals and takes whereas, in the theater, there is no such facility for the performers.

\section{.Drama versus Theatre}

A question revolves in our mind that: what is the difference between drama and theatre?

In simple terms, the main difference between drama and theatre is that the drama is the printed text of a play while the theater is the actual production of the play on the stage.

Drama and Theater are two words that we often use interchangeably as both of them are related to performing arts. However, there is a distinct difference between these two words and in this article we are going to look at the difference between drama and theater.

\section{Theatre in India}

The earliest form of classical theatre of Indiawas the Sanskrit theatre which came into existence only after the development of Greek and Roman theatres in the west. $^{[7]}$ (Despite its name, Sanskrit theatre was not exclusively in Sanskrit language. Prakrit was also used in addition to Sanskrit. With the Is lamic conquests that began in the 10th and 11th centuries, theatre was discouraged or forbidden entirely. ${ }^{[9]}$ Later, in an attempt to re-assert indigenous values and ideas, village theatre was encouraged across the subcontinent, developing in a large number of regional languages from the 15 th to the 19th centuries. ${ }^{[10]}$ Modern Indian theatre developed during the period of colonial rule under the British Empire, from the mid-19th century until the mid-20th. ${ }^{[11]}$ In order to resist its use by Indians as an instrument of protest against colonial rule, the British Government imposed the Dramatic Performances Act in 1876. From the last half of the 19th century, theatres in India experienced a boost in numbers and practice. After Indian independence in 1947, theatres spread throughout India as one of the means of entertainment. As a diverse, multi-cultural nation, the theatre of India cannot be reduced to a single, homogenous trend. In contemporary India, the major competition with its theatre is that represented by growing television industry and the spread of filmsproduced in the Indian film industry based in Mumbai (formerly Bombay), known as "Bollywood". Lack of finance is another major obstacle.

Forms of Indian Theatre: Among the many forms of Indian folk theatre. Bhavai (strolling players) is a popular folk theatre form of Gujarat, said to have arisen in the 14th century AD. Bhaona and AnkiyaNats have been practicing in Assamsince the early 16th century .Jatrahas been popular in Bengal and its origin is traced to the Bhakti movement in the 16th century. Another folk theatre form popular in Haryana, Uttar Pradesh and Malwa region of Madhya Pradesh is Swang, which is dialogue-oriented rather than movement-oriented and is considered to have arisen in its present form in the late 18th - early 19th centuries. Yakshagana is a very popular theatre art in Karnataka and has existed under different names at since the 16th century. Kathakali is a form of dance-drama, characteristic of Kerala, that arose in the 17th century.

Dramaturgy 
The word Dramaturgy, is derived from the greek word, ie: 'to write a drama'. Its current use, to mean 'the study of dramatic composition and the representation of the main elements of drama on the stage, appears first in the eponymous work Hamburg Dramaturgy (1767-69) by Gotthold Ephraim Lessing. Lessing composed this collection of essays on the principles of drama while working as the world's first dramaturg at the Hamburg National Theatre. Dramaturgy is distinct from play writing and directing, although the three may be practiced by one individual. ${ }^{[11]}$ Some dramatists combine writing and dramaturgy when creating a drama. Others work with a specialist, called a dramaturg, to adapt a work for the stage. Dramaturgy may also be broadly defined as 'adapting a story to actable form'. Dramaturgy gives a performance work foundation and structure. Often the dramaturg's strategy is to manipulate a narrative to reflect the current Zeitgeist through cross-cultural signs, theater and film historical references to genre, ideology, role of gender representation etc. in the dramatization.

Dramaturgy[12], the art or technique of dramatic composition or theatrical representation. In this sense English dramaturgy and French dramaturgie are both borrowed from German Dramaturgie, a word used by the German dramatist and critic Gotthold Lessing in an influential series of essays entitled HamburgischeDramaturgie ("The Hamburg Dramaturgy"), published from 1767 to 1769 . The word is from the Greek dramatourgía, "a dramatic composition" or "action of a play."

\section{Experiments in Dramaturgy}

I always have this question in my head, how do we use design and technology to do social intervention, or in theatre, breaching experiment, which involve breaking traditional norms and seeing how people react. To help people to have a better understanding of sociological ideas.Before going further lets see a Shakespeareanquote "All the world's a stage and all the men and women merely players"

This theatrical metaphor of human interaction shows that experiments have been done since ages.It is argued the elements of human interactions are dependent upon time, place, and audience and the goal of this presentation of self is acceptance from the audience through carefully conducted performance.

So here's the big question: If all the world is a stage, how do we make people aware of being players in the theater of everyday life? How will they react when they realize they are being watched by the audience?
Drama and Real Life

Drama and real life are two sides of a coin. Sometimes we need to act in life according to various situations in demand. We play dual roles and get so engrossed in the character that we forget what we really are. Then we startmissing our real identity. Conflicts begin within us,graduallywe as actorsmove on shaping our lives and just because we haven't prepared ourselves earlier we commit errors at times. This quote supports this view, "All the world's a stage and most of us are desperately unrehearsed." Sean O'Casey

Alfred Hitchcock also says, "What is drama but life with the dull bits cut out."

Some of the famous Dramatists of India: Asif Currimbhoy is the most prolific playwright of postindependence period is Asif Currimbhoy, who has written and published more than thirty plays.Badal Sircar, a prestigious name in the realm of contemporary theatre represents the New Theatrical Movement in India. He has created an appropriate 'people's theatre' that is, a theatre supported and created by people. Chandrashekhara Kambara, a prominent writer in Kannada language, he is known for his effective usage of North Karnataka dialect of Kannada in his plays and poems. His plays revolve around folk or mythology inter-linked with contemporary issues.Girish Karnad with the capacity of writer, director and actor substantially contributed to enrich the tradition of Indian English theatre. A writer of Kannada plays, Karnad made a noteworthy impact with Yayati and more so with Tughlaq. He borrowed his plots from history, mythology and, old legends but with intricate symbolism, he tried to establish their relevance in contemporary sociopolitical conditions. Harindranath Chattopadhyay- another playwright who has made significant contribution to the growth of Indian English drama. Mohan Rakesh, a striking dramatist who made his impact in the 1960s, the plays of Mohan Rakesh are the creations of a sensitive mind exploring the world of human emotions caught up in the hard realities of life. Ashadhka Ek Din (1958), a lyrical play based on the life of Kalidasa, evokes the pathos inherent in life.Nissim Ezekiel: He is acknowledged for his exceptional poetic creed and rare dramatic sensibility. Nissim Ezekiel's Three Plays (1969) including Nalini: A Comedy, Marriage Poem: A Tragi Comedy and The Sleepwalkers: An IndoAmerican farces are famous. Songs of Deprivation (1969) is also a short play by Ezekiel. Vijay Tendulkar: Indian theatre gained immensely through Tendulkar's Marathi play, Shantata ! Court Chalu Aahe; it reveals the shocking streaks of cruelty hidden below the ordinary middle class 
veneer. Bold themes are dealt by him in a serious manner. Vijay Tendulkar symbolizes the new awareness and attempts of Indian dramatists of the century to depict the agonies, suffocations and cries of man, focusing on the middle class society. In all his plays, he harps upon the theme of isolation of the individual and his confrontation with the hostile surroundings.

There are many more such prolific writers in this list, Last but never the least to be mentionedis Mahesh Dattani: He is the first playwright in English to be awarded the SahityaAkademi award. Born on August 7, 1958, Mahesh Dattani received his early education at Baldwin's High School and then went on to join St. Joseph's College of Fine Arts and Sciences, Bangalore, Karnataka.

Prior to his stint with the world of theater Mahesh used to work as a copywriter in an advertising firm. He has also worked with his father in the family business. In 1984 he founded his playgroup 'Playpen' and in 1986 he wrote his first play 'Where There's A Will'. Since then he has written many plays such as Tara, Night Queen, Final Solutions and Dance Like A Man. All the plays of Mahesh Dattani are based on the social issues. Apart from theater Mahesh Dattani is also active in the field of film making. His films have been appreciated all over the world. One of his film 'Dance Like A Man' has won the award for the best picture in English awarded by the National Panorama.

Besides being a playwright and a director, Mahesh Dattani adorns the mantle of a teacher with equal ease. He teaches theater courses at the summer session programmes of the Portland University, Oregon, USA. He also imparts training in the field of acting, directing and play writing at his own theater studio in Bangalore.A director, actor, dancer, teacher and writer, Mahesh Dattani has the versatile personality.

Plays of Mahesh Dattani emerged as 'fresh arrival' in the domain of Indian English drama in the last decade of the twentieth century. His plays deal with contemporary is sues. They are plays of today sometimes as actual as to cause controversy, but at the same time they are plays which embody many of the classic concerns of world of drama. Dattani's plays have a universal appeal. They can be staged anywhere in the world, they would draw full attention of the audience. Dattanimoulds his subject in such a way that it is both topical as well as appealing. His plays speak across linguistic and cultural barriers. Dattani makes an abundant use of Indian mythology, rituals and traditions and contemporary problems, India is beset with but he elevates these themes to a higher level, touching the human chords that emanate love, happiness, sexual fulfilment and problem of identity. Though he lives in Karnataka, he writes about the whole nation of India, about the whole world he lives in. It is in the fitness of things that we must make an attempt at evaluating the playwright's thematic concerns as well as his exploration of, and experimentation with stage.

Dattani's plays are remarkable for his technical craftsmanship. He ensures that the enactments on stage will be effective when detailed stage direction are given. He uses space very skillfully, sometimes confining and sometimes widening. He moves from one part of the stage to another, from one level of the stage to another and he lights up different area of the stage at different time. As he does this his characters move in time. Age becomes youth 1990s become 1947 and past, present and future come together. The complex structure of the plays matches the complex and disturbing thematic quality. Dattani very often places a character at a higher level so that the play is seen froma review point.

Dattani says theatre has always been a mirror for man and a reflection of his words, the eternal conflicts that plague him, through which he has experienced the range of human emotions. Man has created a very complex thing called theatre, a language that has the ability to redefine the natural concepts of time, space and movement. Through his language of theatre he has been able to recognize himself for who he is, what he has made of himself and what he aspires to be.

Tarais Mahesh Dattani's two-act drama,This drama is about a girl named " tara". Who like to shine just like hername. Right from the very start we can see the gender discrimination issue. She comes to know that her father gives importance to her brother rather than her. But later on she realizes that it is her mother who discriminates between them when she comes to know that at age 3 her mother gave third leg to her brother that was suited for her.

The stage in Tara is a multilevel set. The lowest level occupies a major portion of the stage.It represents the house of the Patels.it is seen only in memory. The next level represents the bedsitter of the older Chandan in a suburb of London. There is a small bed in the foreground.....wallpaper can also be seen. This is the only realistic level. Behind a higher level is a chair in which Dr. Thakkar remains throughout the play....On the stage level running along the cyclodrama and in a L- shape downstage right is the galli outside the Patels...

Dance Like a Man is a story ofa man trapped by circumstances, a woman caught between ambition and family life. When the choice is between dreams and reality, the latter always wins. Mahesh Dattani's 'Dance Like A Man' centers on an individual's plight, where a dying form 
of art serves as the backdrop. In this play the characters switch roles. Jairaj turns into Amritlal (Father) by simply wrapping the shawl The shawl has special importance in the play Amrit proudly wraps it around himself.Viswas is intrigued by ornate cupboard. A solid rosewood, every article in the house is antique.

Seven Steps around the Fire is one of the famous Radio plays of Mahesh Dattani. It was first broadcasts as Seven Circles Around the Fire by BBC Radio 4 on 9 January, 1999. The play was first performed on stage at the Museum Theatre, Chennai, by MTC production and The Madras Players on 6 August 1999. The play uncovers the truth behind the murder of Kamala, a eunuch through Uma Rao, who is the daughter of the Vice Chancellor of Bangalore University and the wife of the Chief Superintendent, Suresh Rao. Uma teaches Sociology in Bangalore University. She uncovers the reality behind the murder of Kamala during working on her research paper titled "Class-and GenderRelated Violence". In all these above plays the stage setting and narrative techniques are amazing and remarkable.

\section{CONCLUSION}

The playwrights of the modern era have evolved a new narrative techniques. They have over shadow the ancient prejudice that theaters have limitation and are bonded. The narrative technics of Mahesh Dattani exhibits his plays in such a way that it makes the audience feel that they are lost with the characters in their world. The modern movie or the television shows is nothing but the modified and advance form of these theater shows. According to Dattani the theatre is a mirror for the man, a reflection of his words and shadow of his deeds.

\section{REFERENCES}

[1] Elam, Keir. 1980. The Semiotics of Theatre and Drama. New Accents Ser. London and New York: Methuen. ISBN 0-416-72060-9

[2] Fergusson Francis. 1949. The Idea of a Theater: A Study of Ten Plays, The Art of Drama in a Changing Perspective. Princeton, New Jersey: Princeton UP, 1968. ISBN 0-691-01288-1

[3] Burt, Daniel S. 2008.The Drama 100: A Ranking of the Greatest Plays of All Time. Facts on File ser. New York: Facts on File/Infobase. ISBN 978-0-8160-60733.

[4] Banham, Martin, ed. 1998. The Cambridge Guide to Theatre. Cambridge: Cambridge University Press. ISBN $\underline{0-521-43437-8}$
[5] Originally spelled theatre and teatre. From around 1550 to 1700 or later, the most common spelling was theater. Between 1720 and 1750, theater was dropped in British English, but was either retained or revived in American English (Oxford English Dictionary, 2nd edition, 2009, CDROM: ISBN 9780199563838). Recent dictionaries of American English list theatreas a less common variant, e.g., Random House Webster's College Dictionary (1991); The American Heritage Dictionary of the English Language, 4th edition (2006); New Oxford American Dictionary, third edition (2010); Merriam-Webster Dictionary (2011).

[6] Carlson, Marvin. 1993. Theories of the Theatre: A Historical and Critical Survey from the Greeks to he Present. Expanded ed. Ithaca and London: Cornell UP. ISBN 0-8014-8154-6.

[7] Richmond, Farley P., Darius L. Swann, and Phillip B. Zarrilli, eds. 1993. Indian Theatre: Traditions of Performance. U of Hawaii P. ISBN 978-0-8248-13222 .

[8] Brandon (1997, 72) and Richmond (1998, 516).

[9] Brandon (1997, 72), Richmond (1998, 516), and Richmond, Swann, and Zarrilli (1993, 12).

[10] Richmond (1998, 516) and Richmond, Swann, and Zarrilli (1993, 13).

[11] Cardullo, Bert. What is Dramaturgy? New York: Peter Lang Publishing, 2005. p. 4.

[12] Copied from encyclopedia Britannica. 